\title{
Ectopic expression of C-terminal tubulin variants alters wood composition and structure in Populus
}

\author{
Prashant Swamy ${ }^{1}$, Feng Long ${ }^{1}$, Batbayar Nyamdari ${ }^{1}$, Jeng-Der Chung ${ }^{2}$, Shawn Mansfield ${ }^{3}$, Scott Harding ${ }^{1}$, \\ Chung-Jui Tsai ${ }^{*}$ \\ From IUFRO Tree Biotechnology Conference 2011: From Genomes to Integration and Delivery \\ Arraial d'Ajuda, Bahia, Brazil. 26 June - 2 July 2011
}

Cortical microtubules are cytoskeletal components that are relevant to the bioenergy and forest products industry due to their postulated role in orchestrating cellulose microfibril deposition during cell wall formation. The microtubule component proteins $\alpha$ - (TUA) and $\beta$-tubulins (TUB) are encoded by multi-gene families with very high overall sequence homology across species. To advance our initial characterization studies (Oakley et al., 2007), we have developed a suite of transgenic Populus that exhibit perturbed TUA to TUB transcript ratios, or that express tubulin PTM mimics. Most of the construct combinations resulted in abnormal organogenesis and vascular development, and failed to produce viable plants. Only three of the combinations led to wholeplant regeneration, and interestingly, all three featured the C-terminal variants. This is significant because the C-terminus is the post-translational modification (PTM) hot-spot in animal tubulins. One of the PTM mimics that we developed lacks a C-terminal tyrosine, thought to be the target of a tyrosine cleavage and re-ligation cycle important for tubulin regulation in animal cells. The transgenic trees appeared morphologically normal, but exhibited a range of epinasty and twisting phenotypes in mature leaves. Bark color was noticeably lighter in the transgenics. Microfibril angle, wood density, lignin content, lignin structure and metabolic profiles were altered in the transgenic wood. The results are consistent with a function of microtubules and microtubule PTMs for plant development and cell wall biogenesis in Populus, and offer novel strategies to manipulation of wood properties.

\section{Author details}

${ }^{1}$ University of Georgia, USA. ${ }^{2}$ Taiwan Forestry Research Institute, Taiwan. ${ }^{3}$ University of British Columbia, Canada.

Published: 13 September 2011

doi:10.1186/1753-6561-5-S7-P76

Cite this article as: Swamy et al.: Ectopic expression of C-terminal

tubulin variants alters wood composition and structure in Populus. BMC Proceedings 2011 5(Suppl 7):P76.

Submit your next manuscript to BioMed Central and take full advantage of:

- Convenient online submission

- Thorough peer review

- No space constraints or color figure charges

- Immediate publication on acceptance

- Inclusion in PubMed, CAS, Scopus and Google Scholar

- Research which is freely available for redistribution

* Correspondence: cjtsai@uga.ed

${ }^{1}$ University of Georgia, USA

Full list of author information is available at the end of the article

(C) 2011 Swamy et al; licensee BioMed Central Ltd. This is an open access article distributed under the terms of the Creative Commons 